\title{
Jürgen Habermas and the Political Realism: A Critique
}

\author{
Emanuele Castrucci
}

Department of Law, University of Siena, Italy

Copyright (C) 2015 by authors, all rights reserved. Authors agree that this article remains permanently open access under the terms of the Creative Commons Attribution License 4.0 International License

\begin{abstract}
The essay discusses Habermas' defense of cosmopolitic rights. Using Carl Schmitt's categories and the principle of political realism, the author shows the limits of Habermas' idea of human rights as legal rights and not simply as moral rights. The impossibility for Habermas to find a solution to the difficult relationship between moral and legal dimensions of human rights proves that the theory of human rights is a mere ideology.
\end{abstract}

Keywords Legitimacy, Human Rights, Political Realism

Today there is in vogue a humanitarian religion that regulates the expression of people's thoughts, and if by chance someone defies it, he seems monstrous, just as in the Middle Ages anyone denying the divinity of Jesus would have seemed monstrous.

(V.Pareto, Cours di sociologie générale, § 1172, 1)

Die Menschheit entsteht durch Propaganda. (G. Benn, Der Ptolemäer. Lotosland).

\section{Introduction}

That the civitas maxima progress promised by Kant and Kantian idealists reveals itself today, in the phase of multi-ethnic coexistence that is supposed to herald its concrete realization, a formless, degraded civitas, is a paradox that deserves attention. There is in it perhaps a kind of necessity, caused surely by the programmatic disparity that, at least for those still lingering within the Kantian viewpoint exists between what is and what ought to be, between theoretical dimension and historicity. But caused, further back, by the very nature of the juridical means invoked in order to ensure the success of the pan-communicative cosmopolis. I refer, in the terms Habermas uses, to the so-called law as universal medium, or «category of social mediation between facts and norms» 1: a

1 See J. Habermas [1] espec. chapter I. See further Id. [2]. By mere way of example: «Our problematic situation [...] takes for granted the existence of a convenient, non-problematic medium [zweckgemässig] such as decreed, coercive law $[\ldots]$. Especially since in the complex societies of modernity law that claims contradictorily to embody a certain moral content and simultaneously to remain a neutral technique of communication. This while it is by now clear - especially in light of recent international events, marked by the experience of 'humanitarian' wars and the widespread, uncontrolled problem of mass immigration - that the liberal dream of identifying law (with its inseparable centralized jurisdiction) as the universal means of resolving conflicts corresponds to an abstract normative ideal that does not stand up to criticism stemming from any serious, realistic investigation.

Nevertheless, the temptation to produce facile neutralizations (carefully dissembling the ideological manipulations that from time to time are put in place) continues to be strong and to show up even within theorizations that claim to be a rational response to the logic of violence that inspires the technostructures of global power. This is certainly so in regard to Jürgen Habermas' theory of communicative action, which despite its stated intentions ends up substantially reinforcing the rationales of already strong powers, and therefore lining with cosmopolitanhumanitarian justifications the extreme developments of a doctrine of the intimately coercive costitutional-liberal State. But it is also true that this project does not always succeed in obtaining the desired results for those who conceived it. And this - I would tend to believe - fortunately for everyone concerned, since in a hypothetical appraisal the damage caused by the extension to a cosmopolis, through the juridical medium, of alleged universal ethical models would certainly outweigh the goals of civility that this path ensures.

In this paper I examine some texts, in my view highly questionable, in which Habermas - starting with topics developed in his more or less recent major theoretical works, such as Theorie des kommunikativen Handelns (1981) and Faktizität und Geltung (1992) - argues in favor of a cosmopolitical law. And he does so in relation to the above-mentioned concrete problems, i.e.: a) a universalistic

(whether Asian or European) there seems to be no other functional equivalent able to absolve the same integrative functions as positive law. The artificiality of these types of norms - together liberal-coercive and civil-libertarian - has also been able to generate an abstract form of civic solidarity [staatsbürgerlich] pledging to each other outsiders who want to continue to remain such»: Habermas [3] p. 180. 
moral content incorporated into law as medium; b) completion of the historical-cultural enlightenment project through the judicial but perhaps also military imposition of the ideology of human rights. The two topics are obviously intertwined. Their contextual discussion will allow me to better clarify the standpoint, openly alternative to that of Habermas, from which my criticism moves.

\section{Habermas' Arguments}

It is clear that for Habermas law serves essentially as a medium for institutionalizing of claims originating in a moral rationalism. Large sections of Faktizität und Geltung (but even further back, exemplarily, the conclusive considerations of his Theorie des kommunikativen Handelns) are devoted to illustrating what is seen as the fundamental function, exercised by law, of reinforcing the morality of reason (Vernunftmoral). «My argument - Habermas maintains - is that legal rules and moral norms, after having been simultaneously differentiated from traditional ethics [...] develop in parallel as two different types of rules of action, which yet are able to integrate with each other» 2 .

This should not, however, authorize the revival of classical natural law thought patterns: as Habermas takes pains to clarify,

«this reference to morality should not induce us to subordinate law to morality in the sense of a hierarchy of norms. The idea of a "hierarchy of sources" belongs to the pre-modern world of law. Rather, autonomous morality on the one hand and positive law on the other are arranged in a complementary relationship» 3 .

Now, the theoretical topic that best exemplifies this view of the complementarity of law and morality is no doubt that of human rights: a topic that by no accident plays a central role in the late-Enlightenment project of refurbishing the Kantian idea of cosmopolitical law4. Human rights, despite their purely moral content, would seem for Habermas to possess, on an equal footing with actual subjective rights, a logical structure suitable for receiving positive satisfaction in a system of binding norms.

But on this point many doubts could in truth issue forth, especially about the argument advanced in some of Habermas' recent essays, where he addresses - without evading, it would seem, a comparison with strongly divergent theoretical positions - the problem of the practical

\footnotetext{
2 Habermas [1] p. 104 ff. (Habermas' italics).

3 He goes on to say: «Moral and juridical questions refer clearly to the same problems: that is, how justified norms can legitimately order between them interpersonal relations or coordinate actions, how conflicting actions can be resolved by consensus against the background of intersubjectively recognized rules and normative principles. Moral and legal questions nevertheless refer to the same problems in respectively different forms») (ibid).

4 For an exact, even historical-philological reconstruction, of the topic, see lastly G. Marini [4].
}

consequences of his own conception of human rights as a universal source of legitimacy. And yet sooner, of modern law as a rational means of neutralizing conflict, placed in close connection with the principles of Kant's morality based on reason, which defines itself as evident 5 .

First, his evaluative premise, which underpins the Kantian project of re- actualization of the idea of cosmopolitan law, appears thoroughly postulatory. When he states that "in any case, the moral universalism that guided Kant's endeavor remains the fundamental intuition capable of establishing the guiding criteria" 6 , Habermas seems to overlook the fact that this practical-moral self-comprehension of modernity is not the only one possible, and that in any case the intention, proclaimed by any historical force, to 'represent' the interests or the universal value of humanity as a 'whole', seems hypocritical.

In truth, as we can easily learn from the lesson of political realism, «Wer Menschheit sagt, will betrügen», or: anyone who speaks of humanity is out to deceive. This consideration, far from being, as Habermas would like, a «cloying shred of German ideology» $(1998,181)$ manages to demonstrate adequately how the very intention of juridical globalism - to achieve humanity's moral unity, unified under a single law and a single jurisdiction - conceals a desire to eliminate the discriminatory question of "who" should actually administer the tenets of such a religion of a unified humanity by assuming the additional power resulting from reinforced legitimacy, put in place in the facile terms of an ethic of (good) intentions. Whoever is called materially to officiate the rites of the religion of human rights ends up actually deciding on the concrete allocation of power, in the form of "rights", in the various spatial spheres in which the universal is necessarily subdivided.

This willful blindness to the element of decision, sublimated into a neutralizing ethics of discourse, has always been one of the weaker points of Habermas' theoretical construct, to the point of arousing the criticism of careful (and unbiased) observers, who have an easy time identifying the specifically deficient aspect of his theory of communicative action in the fact that

«it ignores the problem of the relationship between language and power, the problem of who decides on the rules of language and the modes of formation of interpersonal and social communication. (...) The function of abstract law and formal equality lies in being the historical forms in which a power is structured. Therefore one cannot request of this law [even in the form of human rights and 'cosmopolitical law', E.C.] a universal truth whose assertion would require the system to negate itself. Negate that is the original (constituent) decision that generated it by establishing the distinction between positive law and natural law, between law as social

5 I refer essentially to the essays contained in J. Habermas [2]. 6 Habermas [2] p. 219. 
technique and law as measure of reciprocity» 7.

The relevancy of Hobbes' question Quis iudicabit? Quis interpretabitur? - as I said - thus returns. A supranational potency, a world «Super-State» 8 , or perhaps a universal court of justice 9? Whatever the answer, Carl Schmitt's observation remains valid: if a historical subject, who necessarily is a stakeholder among other stakeholders, intends to impose on other subjects or peoples certain values in the name of humanity,

«his is not a war about humanity, but a war for which a given force seeks to take possession, against his opponent, of a universal concept in order to identify himself with it at the expense of his enemy, in the same way that one can use the concepts of peace, justice, progress and civilization wrongly, to claim them for oneself and snatch them from one's enemy. 'Humanity' is [in fact] a particularly efficient tool of imperialist expansions [...]. By now we know the secret law of this vocabulary and are aware that today the most terrible war can only be undertaken in the name of peace, and the most abject inhumanity only in the name of humanity» 10 .

In any case, Habermas implicitly recognizes the centrality of Schmitt's critique, when in the same text 11 he expresses - or rather makes a show of expressing - a desire to undertake an analysis of it. And he does so correctly at first in identifying two premises from which this criticism proceeds, summarizeable in the following thesis: $a$ ) the politics of human rights serves the purpose of laying down rules that are part of a universalistic morality; $b$ ) since moral judgments obey a 'good/bad' code, any negative moral evaluation of one's opponent destroys the possibility of applying juridical-institutional limit to the political conflict that opposesit 12 .

Habermas intends to counter these two theses, in which he recognizes the logical premises of Schmitt's overall critique, by referring to his own conception of the aforementioned complementary relationship of morality and law. But it does

7 P. Barcellona [5] p. 40-41. Such as to be able to conclude in drastic fashion that «in fact, the exercise of so-called rational competence coincides with the exercise of a manipulative competence» (p. 47).

8 On which H. Lübbe's timely criticisms [6] must be seen

9 As already proposed seventy years ago by H. Kelsen [7].

10 C. Schmitt [8] p. 55 and 94: «... So ist das kein Krieg der Menschheit, sondern ein Krieg, für den eine bestimmte Macht gegenüber seinem Kriegsgegner einen universalen Begriff zu okkupieren sucht, ähnlich wie man Frieden, Gerechtigkeit, Fortschritt und Zivilisation mißbrauchen kann, um sie für sich zu vindizieren und dem Feinde abzusprechen. 'Menschheit' ist ein besonders brauchbares ideologisches Instrument [...]. Wir kennen das geheime Gesetz dieses Vokabulariums und wissen, daß heute der schrecklichste Krieg im Namen des Friedens... und die schrecklichste Unmenschlichkeit im Namen der Menschlichkeit vollzogen wird».

11 Kants Idee des ewigen Friedens - aus dem historischen Abstand von 200 Jahren, §IV.

12 «a) die Politik der Menschenrechte dient der Durchsetzung von Normen, die Teil einer universalistischen Moral sind; $b$ ) da moralische Urteile dem Code von 'Gut' und 'Böse' gehorchen, zerstört die negative moralische Bewertung (eines politischen Opponenten bzw.) eines Kriegsgegners die rechtlich institutionalisierte Begrenzung (der politischen Auseinandersetzung bzw.) des militärischen Kampfes»: see Habermas [2] p. 221. so by throwing on the carpet - and having them pass as cogent - neo-enlightenment value judgments far from taken for granted: Habermas' argumentation, as I said, just makes a show of assuming "metacritically" as an object of critical discussion positions of value pertaining to non-communicating systems of thought with his eternal Kantianism, and therefore not accepted in their inherent radicalism, which the ethics of discourse - this time not very ethically - prefers to ignore, when not entirely dispel13.

\section{Misrepresentations of Kant's Universalism}

To the first premise («the politics of human rights serve the purpose of imposing norms that are part of a universalist morality»), stated laconically and with a rather labored «falsity»14, Habermas merely repeats himself by adding - in the initial phase - a series of plain historical facts:

«Human rights in the modern sense dates back to the Virginia Bill of Rights, the American Declaration of Independence of 1776, and the Declaration of the Rights of Man and of the Citizen of 1789. These declarations were inspired by the political philosophy of rational-legal authority, particularly in Locke and Rousseau» (ibid).

These historical facts are intended to introduce, by presenting it rhetorically as non-problematic precisely because historically justified in such a way as to be postulated as definitive, the notion - actually very much debatable in a cultural context that is claimed to be fully secularized - of «superpositive validity» («überpositive Geltung») 15. It should be noted in this regard that Habermas, usually so careful in his elaboration and in the use of his principles of interpretation, bends over backwards in order to avoid seeing the puritan theological-political substratum which is part-and-parcel of the concept of «inherent right»-

13 In this regard, we find instructive the warning - which rings like a real call to order - that in another place Habermas addresses to Western intellectuals who identify with the leftist project of government: «Western intellectuals should be careful not to confuse their self-critical discourse on Eurocentric prejudices with debates that others undertake with them»: Habermas [2] p. 181, Habermas' italics. Who these 'others' are is easily understood after what Habermas affirmed shortly before about the need to redimension (which means: isolate, expunge from the theoretical debate) that «hermeneutics of suspect» that developed in Germany in the wake of Heidegger and Schmitt, in the dual form of a critique of reason and a critique of power (ibid., p. 223). In these calls to order addressed to clercs the left we glimpse an entirely political call (with a sectarian and in no way ethical-discursive tone) to close ranks, not unworthy of some - even well known to Habermas - forms of socialism.

14 "While the first premise is false, the second premise - if it is referred to the politics of human rights - suggests an erroneous presupposition»: Habermas [2] p. 221.

15 «It is no coincidence that only in these early constitutional texts do human rights take on a concrete form. Here they appear as fundamental rights guaranteed in the framework of a national legal system. Nevertheless, they seem to have a dual character: while as constitutional norms they have positive validity, as rights due to every human person they also maintain a superpositive validity» (ibid) 
the notion conceptually intrinsic to that of human rights and, I would add, in all value positions related to the idea of a universal morality.

In his proposed reconstruction, Habermas insists on the legality $a b$ origine of fundamental rights (and human rights), in order to keep his theoretical position safe from the risks arising from an accusation of undue 'moralization' of the political dimension, which he is well aware of and whose degree he is unwilling - in this case with undeniable intellectual honesty - to preventively underestimate 16 . But this recognition is not accompanied - as would be expected by any serious inclination to doubt his value presuppositions, whose postulatory character is obvious.

Habermas' text needs to be studied very carefully. To Schmitt's remark, aimed at exposing the hypocritical moralizing function of human rights, Habermas never tires repeating that

«the concept of 'human rights' does not have a moral origin, but is rather a specific form of the modern concept of 'individual rights', namely a specifically juridical category. Human rights have been from the start ["von Haus aus"] of a juridical nature. What gives them the appearance of moral rights is not their content [...], but rather a sense of validity [Geltungssinn] that projects them "beyond" all national juridical systems» 17 .

In other words: the fundamental rights (and with them the rights of man, which should form the foundation of the cosmopolitical community) are able to add a universal moral content (deriving from that trans-systemic «sense of validity» assumed unproblematically as common to all evolved juridical systems) with a juridical structure which makes them coercible (deriving in turn from the evolution of subjective rights positivized within the jurisdiction of the democratic State of law). Which, if accepted, would make it possible to speak - with true short-circuit logic - of «universal rights» in the sense of being universally receivable, justified definitively in terms of rational argumentation. Habermas does not seem to entertain any doubts. It is true - he concedes - that «despite their claim to universal validity, human rights have been able to take on an unequivocally positive form only in the national juridical systems of democratic States», but it is also true that «they are waiting to be institutionalized within the framework of the cosmopolitical system which is coming to light in these years» (so Habermas [2], p. 225), where it is clear that this institutionalization should by now resemble a sort of imperative. This is so since «the moral universalism that guided Kant's endeavor remains the fundamental intuition

16 «The core of truth [of Schmitt's critique] lies in the fact that an immediate ["unvermittelte"] moralization of law and politics would effectively crush those "protected areas" ["Schutzzonen"] of law that we [...] want to safeguard for subjects of rights. It is however mistaken to believe that to avoid this moralization we must liberate (or make a clean sweep of) the international politics of law and the law of morality»: see Habermas [2] p. 233.

17 Habermas [2] p. 222, Habermas' italics. capable of establishing the guiding criteria [of a] practical-moral self-comprehension of modernity» 18.

It is disconcerting how Habermas can so nonchalantly put together, and pass as based on the level of argument, a series of statements (and correlative value judgments) of an ideological nature - and still anything but universal - of which he strives to hide the fact that it functions to serve a logic of interests whose success is certainly not due to the intrinsic goodness of the arguments that support it, but rather to a globally favorable balance of forces. What emerges here is the strategic nature of the Habermas project, vainly dissembled in exoteric forms dictated by the theory of communicative action: all in all - we can say - inspired by something not very different from the ancient intent of philosophers to justify that «might isright».

Habermas' strategy of argumentation proceeds in the direction of preventively denying the possibility of overall positions of alternative value, capable of establishing the democratic legitimacy of political identities not attributable to the project of organizing a worldwide command center. The generalizing and neutralizing rhetorical statements that accompany this design do nothing to mitigate the arrogant assumption that determines it: political identities non-compliant with the prevailing ideology (generally inspired by the rhetoric of human rights as the core of legitimacy of the domination exercised by the governing classes) cannot exist even in principle, because dangerous or regressive, for he takes for granted the goodness of a world order conceived self-praisingly as the extreme, epoch-making outcome of the historical and cultural enlightenment project. In other words, no one (no individual, no people, no political community) would, in Habermas' intention, dare to question the desirability of a movement towards world unification and, as inevitable consequence, of a sacrifice of conflicting single wills, whatever shape or form - cultural, sociological, religious - they might take. These single wills must, as a foregone conclusion, be deemed backward, and possibly fall under the trite mechanisms of a line of reasoning that has as its prototype the reductio ad Hitlerum. (The ideological arrogance demonstrated by the governments of the European Union about the so-called «Haider case», in January 2000, takes on here a symbolic value).

Let us consider these arguments which Habermas uses in his essay on the idea of Kant's «perpetual peace» to convince himself that he is neutralizing the critical potential of Schmitt's 'school of suspicion', evading - after a mock debate - its radical impact by reducing it to instances of a vulgar warmongering:

«Schmitt loads the concept of 'Political' with vitalistic valences because he wants to shore up his basic thesis: the creative force of the 'political' must

18 «In jedem Fall bleibt... der moralische Universalismus, der Kant bei seinem Vorhaben geleitet hat, die maßstabbildende Intuition [eines] moralisch-praktischen Selbstverständnis der Moderne»: Habermas [2] p. 219. 
necessarily revert to a destructive force as soon as it strays from the international arena of wolves in which it can release its "conquering violence". By promoting world peace, the global extension of human rights and democracy would unintentionally - have the effect of destroying the limits characterizing juridically compliant [formgerecht] war, authorized by the law of nations. Without this venting in free nature [freie Wildbahn], war would end up flooding the autonomous, civil spheres of life of modern societies, therefore annihilating all the complexity of differentiated societies. Actually, this admonition concerning the catastrophic consequences resulting from the obsolescence of war in terms of juridical pacifism refers to a metaphysic typical of an era, or rather of an aesthetic - today rather outmoded - of so-called "storms of steel"»19.

But Schmitt does not mean this. His intention is to describe and explain real phenomena which are integral to the dimension of the 'Political' - a distinct set of problems already as such qualitatively irregular with respect to the solely moralistic problems of humanity as single moral subject. The key point is rather that the general equality among human beings, axiomatic to the goal of humanity as a single moral subject (and therefore to the effectiveness of universal human rights) is not the goal of real politics, but in a best case scenario (one which does not simply provide an ideological cover for power plays) - a moral ideal of reference.

Kant himself would talk of «regulative idea» - an idea that can never be ipso facto the subject of a juridical question, but that can become - and in fact often does - the most appropriate ideological weapon for prevailing in a political conflict. Who could resist a force that fights under the mantle of the universal value of humanity? And what 'inhuman' (as such easily criminalizable) subject could ultimately act as a counterforce for resisting as such the full realization of the 'good of humanity'? It is in thinking allarmedly of this hypothesis of ideological discrimination from humanitarian motives that Schmitt argues that a moral ideal like that of 'humanity' does not in itself constitute a juridical question 20 .

The theoretical reasons for Schmitt's position appear already quite clear in texts of the late 1920s, thus much earlier than the years of Ex captivitate salus and Glossarium, and they acquire significant premonitory value in relation to our present- day universal ecumenism.

«The idea of human equality contains neither a juridical nor a political nor an economic criterion. Its importance for constitutional doctrine is that it pertains to liberal individualism and upholds the

19 Habermas [2] p. 231.

20 "What on earth is a 'crime against humanity"? Are there perhaps crimes against love?»: C. Schmitt [9] p. 113, cit. in Habermas [2] p. 228-229. principle of fundamental rights. [...] The reference to this general human condition may mitigate certain harshnesses and act in a moderating and relativizing direction, but it cannot constitute a concept [...]. An equality that has no other content than an equality as such common to all human beings would simply be a non-political equality since it lacks the correlative concept of a possible inequality. Every equality acquires its importance and its meaning on the basis of its correlation with a possible inequality. It is all the more intense the greater is the inequality in relation to those who are not part of the equals» 21 .

It is certainly not by imputing to Schmitt's theory of the 'political' inevitable imperialist or warmongering consequencies (and therefore blaming it for a kind of duality in prescriptive terms of the phenomena and regularities described) that Habermas can claim to exorcise the heuristically fruitful function exercised by this theory. But it is obvious that the real reason why Habermas needs to preventively discredit Schmitt's view is that he risks incurring its disruptive impact, condensed in its two constituent polemical statements, which - by specifying more clearly what has already been said (see above, note 14) - can be summarized as follows: $a$ ) it is precisely the politics of human rights that provokes wars which - masquerading as simple "police actions" - take on a dangerous moral valence (dangerous primarily because 'absolutist'); $b$ ) this moralization necessarily produces criminalization: by branding one's adversary as an 'absolute enemy' of humanitarian truth and good, one justifies the most ruthless repression in favor of the 'humanitarian' re-establishment of that truth and good (hence the totalizing logic of 'humanitarian wars').

\section{Three Counter-theses on the Rights of Man}

There is then, as is evident, an absolute logical incompatibility between the communicative-humanitarian Gestalt and the political-realist one, and one of the most significant aspects in which this incompatibility reveals itself lies in the ambiguous moralization of law established by the rights of man (due ultimately to the confusion resulting from an instrumental reading of Kant's texts, between the two classic profiles - the moral one and the juridical one - of Sollen)22. Here it is impossible not to note

\footnotetext{
21 Schmitt [10] p. $226 \mathrm{ff}$.

22 As Habermas himself recognizes, «this is an ambiguity that has generated more than one of bewilderment in philosophical discussion. According to some, the statute of human rights should be placed midway between moral law and positive law. According to others, human rights should - maintaining the same content - have the status of both moral and legal rights: a sort of "valid pre-state law, but not however automatically in force. [...]. These embarrassed formulations seem to suggest that constitutent legislator should simply pave over with positive law moral norms given a priori»: see Habermas [2] p. 221. But the path taken by Habermas for overcoming this dilemma: to declare fundamental rights (and
} 
how there creeps into Habermas' text a serious contradiction between calling, on the one hand, moral the content of fundamental rights and legal the structure that determines its enforceability, and recognizing, on the other, that the «sense of [universal moral] validity» (Geltungssinn) inherent in these 'rights' is only a requirement, or rather a «claim» (Geltungsanspruch) whose effectiveness is not (and cannot be) given, but only postulated on the basis of a need for justification which is not necessarily liable to be satisfied.

A need, therefore, and not an ascertained moral content; a claim, and not a reality, are the characteristics that determine the logical structure of the Menschenrechte in which Habermas tends to see fulfilled the prodigy (which one would not hesitate to define as theological, or rather, theological-political) of the encounter between ontology and morality, between being and having to be.

If we bear in mind this character of a «claim of validity» (Geltungsanspruch) as the constitutive element of the logical form of fundamental rights, then it is incorrect to state, as Habermas does, that

«the fundamental rights governing such general subjects as moral arguments are certainly sufficient to their foundation. These are arguments that justify in what sense the assurance of these rules mirrors the interest of all [sic, E.C.] people as people, therefore in what sense these rules are good for all» 23 ,

\section{or even that}

«this universal validity, in relation to people as such, is a property that fundamental rights share with moral norms» 24 .

These are rhetorical statements which are certainly unimpressive for their rational cogency, but which are justifiable in concrete terms only by postulating the existence of a political power able to enforce them, i.e. to be the sociological condition of their effectiveness. However, such statements betray their nature of dogmas of a claimed neo-Enlightenment political theology - unacknowledged on account of its very neo-Enlightenment claim - in their overlooking the fact, indubitable (and clear in the light of a realistic approach, which in this case too breaks down through a radical nominalistic analysis the eternal humanitaristic universalisms), for which:

i) the rights of man are conceptually a hybrid, located halfway between the juridical and the moral dimension. A hybrid that holds up at the price of taking as a universal

with them human rights) already as such juridically finalized, establishing a gradualist genealogical development starting from the subjective State rights of classical law (almost as if there were no 'leaps' in the logical development of the rule of law and the human rights of the universalist cosmopolis) is even less convincing and conceals unacceptable conceptual approximations.

23 Habermas [2] p. 223. Habermas'italics.

24 Ibidem. In fact «being part of a democratic juridical system, fundamental rights too enjoy (like all other jurdical norms) an ideal validity of their own [Gültigkeit]. In the sense that they are not only effectively applicable [...], but they can also claim legitimacy since liable to rational justification» (p. 222) foundation of validity what is merely a justifying shell (Pareto would speak of mere "derivation») of the factual force that takes on the task of administering those very rights of man;

ii) no juridical norm that has incorporated certain moral contents (even if it claims to raise them to the abstraction of «fundamental rights») can be universal. Only that which is purely formal, strictly speaking, universal, and this is certainly not the case for the rights of man;

iii) no moral norm that aspires to universality can be applied on a practical level unless it is supported by a political force capable of imposing it. But then it can no longer be considered universal, but rather as a projection of this political force. (It is worth mentioning yet again that, as such, a moral norm can at best express a «request» for universality, but a request still originating from a partial subject, tied to concrete perspectives of interest, and not by any idealistic dominus of universality, to be viewed as the theological-political projection of the cumbersome Judeo-Christian God, even if in renewed forms of Kantian puritanism).

These three theses, which impede the preachability of the rights of man as universal rights (and which we could for the sake of convenience call: i) the thesis of the «justifying shell of interest»; ii) the thesis of «embedded moral content»; iii) the thesis of the "necessary ineffectiveness of universality») point out some very embarrassing truths for the new juris-globalist conformism, which sees in the politics of human rights - possibly framed in coercive terms - the virtuous realization of an 'inescapable obligation of morality'. Who would dare - we asked ourselves earlier ironically - take sides with 'evil' against 'good'? Habermas' relentless struggle against barely relativistic or 'contextualizing' value positions 25 leads him to paradoxical (and just till yesterday embarrassing, at least for the left) appeals for an entirely German 'philosophical imperialism', vainly masked by a pan-communicative ideology, of which his essay on "legitimacy by way of human rights" offers significant examples.

In so doing, Habermas refers explicitly to Rawls' idea of so-called overlapping consensus 26 , according to which humanity should be put in a position finally to establish a peaceful coexistence, recognizing in the medium of law essentially in the form of human rights - the sole source of legitimacy, valid for all civilizations (and not just for the Western one):

25 Guilty, in Habermas' own words, of seeing in human rights «the expression of a specifically Western reason, rooted in Platonism. Victim of an 'abstractive prejudice', this reason would place itself outside the limits of its original context and, in so doing, outside of a merely local validity of its would-be universal criteria. Every tradition, image of the world or culture should have inscribed in themselves their respective (and incommensurable) criteria for jup. dging truth and the falsehood»: Habermas, Zur Legitimation durch Menschenrechte, in [3] p. 181.

26 Or consensus reached «by an overlapping» of the moral principles that characterize different cultures, in the belief that these principles are basically homogenous, since traceable to a common core of moral intuitions on which the great prophetic religions of the planet (significantly universalist) converge aborigine. 
«Just as what happened to Christianity during the European religious schism, so too the traditional images of the world are being transformed today under the impulse of the reflection induced by the modern conditions of life - into the 'reasonable comprehensive doctrines' of which Rawls speaks. By this he means an ethical self- comprehension of the world and of the self which - having become reflective - leaves the way open to reasonably foreseeable disagreements with other religious beliefs, with which it is nevertheless possible to agree on the rules of a juridically equalized coexistence» 27.

But it should be noted that all the key points of this quote are highly questionable. It is unclear how this supposed «reflectivity» is capable of bringing about the no less desired «ethical self-comprehension of the world and of the self»: we rather get the impression that his words have, in these contexts of philosophical analysis, miraculous effects, to the point that it should not be surprising to see the reflective method succeed in the difficult task of settling radical value disagreements, comparable to those that occur «with other religious beliefs».

This quasi-thaumaturgic virtue becomes highly implausible if ascribed to procedural reason. Through its effective «reflective» intervention it would be able to rationalize what is irrational, make negotiable what is non-negotiable, as well - at least in part - as juridicizing the 'Political' by a recognition in it of conflicts which however are «reasonably foreseeable» and hence to our great relief relegated to the jurisdiction of the universal! It seems that Habermas, in voicing in passages such as this the needs of the Western political class (linked to social techno-bureacracies, virtually or actually orphans of the Welfare State and anxious to replace it with something equally profitable), has abandoned all 'philosophical' decorum, to the point of declaring indisputable what are just some of the possible options of ordinary political ideology. It is quite clear at this point why any 'hypernormative', moralistic politics wants at all costs to steer clear of direct confrontation with theoretical positions capable of unmasking its unilaterality.

We see here also the profound intellectual reasons for the incompatibility which exists between any normative political philosophy and Schmitt's theory of the 'Political' -: an incompatibility whose clearly visible traces are present in Habermas' recent writings, and that take the form of polemical outbursts which, far from being intellectually exhaustive, degenerate to the logic of political struggle. However, it is the Streit um die Menschenrechte which remains the principal form in which this larger conflict is presented, whose dimensions can well be defined as momentous, between a classical tradition of European thought and a new approach to what Pareto would call

27 Habermas [3] p. 190-191, italics mine. socialist morality, unknown - at least in the same form before the mid- twentieth century and vigorously revived in the nineties after the fall of the Soviet empire28.

This ideological approach is ensconced by Habermas within his theory in the same terms in which it is launched on a planetary scale by the arrogant theology of humanity, whose roots can be found - as has often been noted - in the re-elaboration of the principal monotheistic religions in the forefront at the start of the third millennium29. The dual form in which this theology of humanity is presented Judeo-Christian ecumenism - makes reference to a solidaristic, egalitarian moralism endowed with immense extortionist powers via the inculcation of guilt, against which Nietzsche's classic pages from the Genealogy of Morals remain more than ever timely. These values and thought systems today inspire and deeply determine the ideological orientations and the overall politics of the great pro-universalist powers such as the United States, caricatured by the European Union despite the profuse efforts at re-elaboration by opinion-makers such as Habermas.

\section{Conclusions}

To sum up, I find completely unfounded the general thesis umderpinning Habermas' argumentational system, namely that human rights do not belong to the category of moral rights (which we should translate, as has been said, simply as moral «claims»), but - from the start - to that of actual legal rights, in the form of «subjective rights», endowed with a specific enforceability which is recognized as the differential element determining its juridical stature. In particular, the theoretical solution proposed by

28 In this sense are the essays gathered in the book edited by S. Shute and S. Hurley [11] are representative. R. Rorty's essay is worthy of attention for his discussion of the in favor of an openly anti-foundationalist theory of human rights expressed by the Argentinian E. Rabossi, for whom «the world has changed, and the phenomenon of human rights makes obsolete and irrelevant the search for their philosophical foundation» (ibid., 132). One can only say that, even if (and willingly granted) metaphysical foundationalism no longer poses an inescapable destiny for ethical theory, the purely pragmatic type of justification that Rorty proposes remains very weak. Instead Rorty's following reflection is worthy of attention: "The moral educator will no longer be given the task of responding to the rational egoist when he wonders: "Why should I have a morality?", But rather what to answer the much more frequent question, "Why should I care about a stranger, a person with whom I have no family ties and whose customs bother me?", the answer it traditionally given to the second question is: "Because the bonds of kinship and customs are morally irrelevant, that is irrelevant to the obligations deriving from the fact of recognizing their membership in our own species". This answer has never been very convincing, for the simple reason that it takes for granted that it is the very crux of the problem: whether, that is, the simple fact of belonging to the species can actually be considered a valid surrogate of one's closest relationships» (ibid., 150). - It should be noted, however, that Rabossi's theoretical position appears entirely superficial, in his insistence that a «human rights culture» is by now «an undeniable reality», accepted on a planetary scale even at the institutional level (a recurrent motif in Habermas himself), is sufficient reason to definitively exonerate the philosopher from asking further questions.

29 «The essential content of moral principles embodied in international law - as Habermas himself frequently claims - is in keeping with the normative substance of the great prophetic doctrines and metaphysical interpretations affirmed in universal history": see J. Habermas [12] p. 20. 
Habermas concerning the problem of the relationship between the moral dimension and the legal dimension of human rights 30 appears unsatisfactory first of all on a logical basis. As we noted at the beginning of the previous paragraph, in Habermas' view «the juridical nature of the norms regards their structure, and not their content», which instead is moral and universal. Like other individual rights, human rights certainly have a moral content, but - apart from that moral content - they belong «on the basis of their structure to an system of positive - and binding - law capable of establishing enforceable individual legal claims. For the moral establishment of human rights it would in other words be sufficient to believe that they regulate such general matters" as reflect "the interest of all persons qua persons» 31 . Once again it should be stressed that this is a very weak, unrealistic theoretical solution: there can be no logical universal basis of argumentation for norms that are (as are necessarily juridical norms) related to particular positive- historical conditions. Which means that these requirements - universality and historicity, juridical validity and moral absoluteness - cannot be simultaneously satisfied. As we have said, Habermas mistakes the claim to universal validity advanced for a certain class of norms -: the moral norms related to human rights - for an already established claim to universal validity (and therefore effectiveness) of corresponding juridical-positive norms. The leap is abrupt and not formalizable in rigorous analytical terms. Perhaps only substantialist and intuitionistic premises typical of classical natural law, with their undemonstrable faith in a moral sense seen as infallible organ of judgment secularization of the Aristotelian-Thomist concept of synderesis - could explain, but not authorize, this self-sacralizing mechanism of law: but explaining it on an openly metaphysical level, repudiated as such by those who like Habermas admit only procedural, public, verifiable conceptions of approach to value.

Of little worth, at this point, is the caution with which Habermas accompanies the delicate question of the 'immediate' implementation of moral value, considered in the form of humanitarian politics which supports the judicial enforcement of the rights of man. The «kernel of truth» present in the realistic critique guided by the theory of the 'Political' toward such a 'judicial implementation' Habermas admits - is that «an immediate moralization of law and politics would actually break down those 'protected

30 In his constant preoccupation not to retrace the aporetic paths of classic natural law, which Habermas himself recognizes is completely «ambiguous»: "It is an ambiguity that has generated more than one disconcertedness in philosophical discussion. According to some, the statute of human rights should be placed midway between moral law and positive law. According to others, human rights should present itself - maintaining the same content - both as both moral and juridical rights: a sort of "pre-State" valid law, but not for that automatically in force»: so Habermas [2] p. 221.

31 «Grundrechte regeln [...] Materien von solcher Allgemeinheit, daß moralische Argumente zu ihrer Begründung hinreichen. Das sind Argumente, die begründen, warum die Gewährleistung solcher Regeln im gleichmäßigen Interesse aller Personen in ihrer Eigenschaft als Personen überhaupt liegen, warum sie also gleichermaßen gut sind für jedermann»: Kants Idee des ewigen Friedens, in Habermas [2] p. 223, Habermas'italics. areas' that we [...] still want to safeguard», so that «it would produce in the international arena [...] harmful effects» 32 . But - Habermas continues - the risk is only apparent, and the damaging effects of "moral fundamentalism" can be easily averted. In fact,

«the politics of human rights carried forward by a world organization revert to a fundamentalism of human rights [Menschenrechtsfundamentalismus] only when they provide moral legitimacy, under the cloak of a juridical pseudo-legitimation, to an armed intervention which in fact merely expresses the struggle of one party against another. In cases such as these the world organization (or the alliance acting on its behalf) would commit a 'deception', presenting as a police measure - neutral and justified by executory laws and judgments - what in truth would simply be a military confrontation between warring factions» 33 .

The point is that, in the light of what any serious, realistic investigation shows, that is what always and necessarily occurs: knowledge of the laws inherent in the logic of value 34 , on the one hand, and the realist unmasking of rhetorical weapons, which universalist morality uses on the other, no longer permit any illusions about the fact that Habermas' thesis of the pristine, indestructible juridical stature of the rights of man (seen as an evolutive form in the framework of the cosmopolis, of the subjective rights of the classic State of law) 35 is an ideological thesis endowed with a precise function of post-natural law legitimation of the power structures functional to the domain of certain political parties, which obviously cannot pretend to be a 'totality', but which are aware that only this fiction makes the exercise of their command admissible.

The matter is all the more serious if one thinks that Habermas has hinging on the results of this false demonstration the approach to and then solution of the fundamental problem thrown on the carpet by political realism, leading back to the charge by which «a policy of intervention on human rights must necessarily degenerate into a 'fight against evil'» (so Habermas [2] p. 206) and «total war is simply the form taken by that 'just war' in which any intervention policy in favor of human rights necessarily culminates» (Habermas [2] p. 209). The inevitable consequence is then - and, we have said, could not be otherwise - to immediately criminalize one's opponent by striking him harder thanks to the monopoly of

32 «Der wahre Kern besteht darin, daß eine unvermittelte Moralisierung von Recht und Politik tatsächlich jene Schutzzonen durchbricht, die wir [...] gewahrt wissen wollen. [...] Tatsächlich würde sich in der internationalen Arena eine unvermittelte Moralisierung der Politik schädlich auswirken»: Kants Idee des ewigen Friedens, in Habermas [2 ] p. 233-234, Habermas' italics.

33 Habermas [2] p. 235.

34 Which show us that «those who establish a fixed value at all times, eo ipso, a non-value. The meaning of this determinazione of non-value is the annihilation of non-value»: C. Schmitt [13] p. 80-81, footnote 49.

35 «Das Weltbürgerrecht ist eine Konsequenz der Rechtsstaatsidee»: Kants Idee des ewigen Friedens, in Habermas [2] p. 234. 
moral justification retained by the culturally (and militarily) prevailing 'humanitarian' coalition forces. Military actions renamed and hence legitimated as «police actions» - would then aim at restoring a moral order of the world treacherously dashed by the political criminal of the moment, while the neutrality of cosmopolitical jurisdiction would function as a universal sterilizer, with the specific purpose of extirpating the dimension of the 'political' embodied by any form of political existence that is 'particular', resistant - precisely because of this peculiarity - to standardization.

There are those who, like the libertarian sociologist Belohradsky, have recently reactivated in this very perspective the realist critique of the instrumental use of the idea of «neutrality», by observing how modern politics are entirely focused on the desire to «neutralize», that is to say to proceed toward a continual dislocation of potential places of conflict, to the quest - by its very nature endless - for a claim to rationality able to regulate by law all conflicts. It is clear that by going down this road one overlooks the fact that the terrain on which the political form of human existence rests can never be made neutral, or - what amounts to the same thing - pacified in the sublimated form of universality, under the jurisdiction of a procedural reason understood as the supreme protection and bulwark of impartality 36 . Here, it must be said, impartiality is mystification. And it is significant to have to point out in relation to the thesis of an author like Habermas, who was born as a "culture critic", even if it is true that the transition he underwent from a radical critique of society to what has long been in effect just a sophisticated (and devitalized) form of Kantianism. Certainly, such 'twists and turns' would have been considered just a few decades ago with far greater suspicion by European thought, then perhaps - it must be said - more demanding than today 37.

We must, in the end, have the courage to recognize that human rights - far from being a momentous, definitive acquisition - are a simple ideology that expresses the eternal struggle to exercise a momentary tyranny, justified in moral

36 But instead it is true that «l'absence d'une règle neutre pour resoudre les conflits entre les hommes est une experience inévitable à laquelle personne ne peut se soustraire. Il y a toujours le risque - et exister signifie l'accepter - que les autres ne reconnaissent pas ma différence par rapport à eux. [...] Il y a toujours la possibilité qu'on doive combattre pour sa propre identité». Va ricordato che «la théorie est "pure" en tant qu'elle se place à distance de tout ce qui est enraciné, non répétable, non réproductible, territorialisé, bref, tout ce qui nous engage à prendre position. [...] La polarité ami-ennemi perce à travers la neutralité de l'espace public dépolitisé gouverné par les lois et les appareils administratifs. [...] Le problème politique de notre époque réside dans cette absence d'ennemi, dans ce rejet de la relation ami-ennemi comme intelligible»: V.Belohradsky [14] p. 55, 44, 57.

37 The responsibility for this 'veering' is undoubtedly Habermas' strong tendency to be an interpreter - and one in the forefront - of the leading political tendencies in Western 'leftist government' circles, which indicates - it is impossible to deny - a great 'political' dexterity of adaptation and more than a hint of opportunism. But on this point everything has already been said and the issue has become devoid of theoretical interest. On the drop in tension in Frankfurt criticism I will only recall C. Türcke's [15] pungent observations. terms, over the general system of values 38 , and as such are closely linked to a specific historical- cultural context (that produced by the global dominance of American power politics), which provides their sociological condition of possibility.

This ideology is based on the rejection of the categories of the 'political' and in particular of the workability of the friend/enemy distinction, which - by a kind of irony returns periodically to emerge even in violent forms, even though (or, we should believe, just because) unexplained. Moralization prevents it from being intelligible, because the neutralizing concept of humanity by definition excludes that of enemy39. This makes it clear for what real purposes the idea of crimes against humanity, on the basis of which the International Human Rights Police claims legitimacy, can only result in what one might call a true principle of political management of the moral discrimination of forms of life extraneous to the prevailing project of the socialist fulfillment of modernity, therefore as opponents. It should be recognized that law, in the form of the universalist administration of the rights of man, is hence degraded contrarily to what Habermas himself would like - to a questionable tool of moral propaganda, exposing the connection between propaganda and humanity which Gottfried Benn, with extraordinary premonition, had long derided40.

38 I use these terms («tyranny» over the «system of values») in the specific sense attributed to them in C. Schmitt's essay [16]. The truth is that «no one can evaluate without devaluing, increasing in value, and endorsing. Those who establish values take a stand against non- values»: «Niemand kann werten ohne abzuwerten, aufzuwerten und zu verwerten. Wer Werte setzt, hat sich damit gegen Unwerte abgesetzt»: C. Schmitt (1967), p. 58. From all this we can easily understand the reason (from the «inherent logic of values») why the politics of the rights of man necessarily produces discrimination against one's opponent: «Any regard for one's enemy falls away, indeed turns into a non-value, when the battle against this enemy is a battle for supreme values. Non-value has no right before value, and no price is too high for the imposition of supreme value» («Jede Rücksicht auf den Gegner entfällt, ja sie wird zum Unwert, wenn der Kampf gegen diesen Gegner ein Kampf um die höchsten Werte ist. Der Unwert hat kein Recht gegenüber dem Wert, und für die Durchsetzung des höchsten Wertes ist kein Preis zu hoch»: ibid., p. 61 , italics mine).

39 «Der Begriff der Menschheit schließt den Begriff des Feindes aus»: C. Schmitt [8] p. 54-55. But, to the extent that it subsumes political relationships under the categories of 'good' and 'evil', it transforms the belligerent enemy into «that inhuman monster that cannot only be defeated, but must be permanently destroyed» [«unmenschliche Scheusal, das nicht nur abgewehrt, sondern definitiv vernichtet werden muß»]. The lack of understanding of the anthropological roots of the 'political' ends up inevitably amplifying violence. This belief is clearly expressed and argued in fundamental studies of authors such as René Girard.

40 See the quote here in the epigraph. A reference that is found today mercilessly photographed in the caustic pages of Hans Magnus Enzensberger [17]: «Typical of the West is the rhetoric of universalism. [...] Universalism knows no difference between what is close and what is far away: it is absolute and abstract. The concept of human rights requires on everyone obligations that, in principle, know no borders. [...] However, since all of our options for action are limited, the gap between desire and reality becomes increasingly deep. It soon crossed the threshold of factual hypocrisy. Universalism thus reveals itself to be a moral trap» (ibid., § IX). 


\section{REFERENCES}

[1] J. Habermas, Between facts and norms.Contribution to a discourse theory of law and democracy, MIT Press, Cambridge 1992.

[2] J. Habermas, Die Einbeziehung des Anderen. Studien zur politischen Theorie, Suhrkamp, Frankfurt a.M. 1996.

[3] J. Habermas, Zur Legitimation durch Menschenrechte, in J. Habermas, Die postnationale Konstellation, Suhrkamp, Frankfurt a.M. 1998.

[4] G. Marini, Tre studi sul cosmopolitismo kantiano, Istituti Editoriali e Poligrafici Internazionali, Pisa-Roma, 1998.

[5] P. Barcellona, Dallo Stato sociale allo Stato immaginario, Bollati Boringhieri, Torino 1994.

[6] H. Lübbe, Abschied vom Superstaat, Berlin, Siedler, Berlin 1996.

[7] H. Kelsen, Peace through Law, The University of North Carolina, Chapel Hill 1944.

[8] C. Schmitt, Der Begriff des Politischen, Duncker \& Humblot,

[9] C. Schmitt, Glossarium. Aufzeichnungen der Jahre 1947-1951, Duncker \& Humblot, Berlin 1991.

[10] C. Schmitt, Verfassungslehre, Duncker \& Humblot, München-Leipzig 1928.

[11] S. Shute and R. Hurley, Human Rights - Oxford Amnesty Lectures 1993, Basic Books, New York 1993.

[12] J. Habermas, Vergangenheit als Zukunft, Pendo Verlag, Zürich 1990.

[13] C. Schmitt, Theorie des Partisanen, Duncker \& Humblot, Berlin 1963.

[14] V. Belohradsky, La modernité comme passion du neutre, Le messager européen, No. 2, 1998.

[15] C. Türcke, Gewalt und Tabu. Philosophische Grundzüge, zu KlampenVerlag, Lüneburg 1992.

[16] C. Schmitt, Die Tyrannei der Werte, in: C. Schmitt, Säkularisation und Utopie - Ebracher Studien. Ernst Forsthoff zum 65. Geburtstag, Kohlhammer, Stuttgart-Berlin-Köln-Mainz 1967.

[17] H.M. Enzensberger, Aussichten auf den Bürgerkrieg, Suhrkamp, Frankfurt a.M. 1993. 